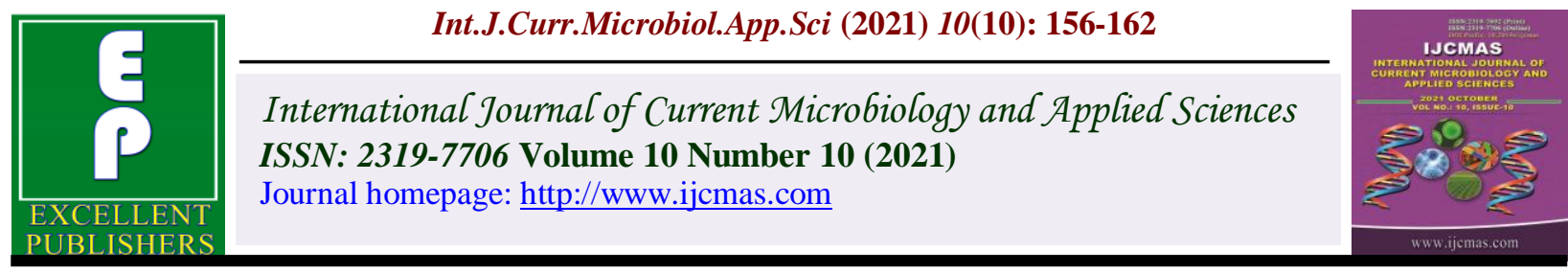

Original Research Article

https://doi.org/10.20546/ijcmas.2021.1010.018

\title{
Adaptive Performance of Five Varieties of Hybrid Citrus in Jingzhou Area Hubei Province
}

\author{
Tian-zhi Gong, Feng Xu and Guiyuan Wang*
}

Yangtze University, College of Horticulture and Gardening, Jingzhou, Hubei 434025, China

*Corresponding author

\section{A B S T R A C T}

Keywords

'Aiyuan 38',

'Daya', 'Chunjian',

'Buzhihuo',

'Wogan',

Adaptability

Article Info

Accepted:

10 September 2021

Available Online:

10 October 2021
In order to understand the growth habits and freeze resistance of the hybrid citrus variety in Jingzhou area, and to provide reference for the introduction of the variety in fruit farmers, and to promote the development of the local citrus industry, the main biological and freeze resistance characteristics of the five hybrid citrus variety were investigated. The results showed that:(1)The growth potential of 'Wo gan' and 'Daya' were the strongest, followed by 'Aiyuan 38' and 'Chunjian', and the weakest growth was 'Buzhihuo';(2) On the performance of summer and autumn shoots, 'Daya' and 'Wogan' were the longest, 'Chunjian' was moderate, 'Aiyuan 38' and 'Buzhihuo' were the weakest; (3) On the aspect of freeze resistance, 'Aiyuan 38'was the strongest, followed by 'Daya' and 'Wogan', the freeze resistance of 'Chunjian' was more weak and 'Buzhihuo' was the weakest;(4) On the other aspects, such as the leaf shape, leaf size, color of tender leaf, thorn density, flower size, inflorescence and so on also had the big difference, but the petal number and the petal color were similar. It could be seen that 'Daya' and 'Wogan' had the best growth potential in Jingzhou area, but their freeze resistance were weak. The growth potential of 'Aiyuan 38' and 'Chunjian' were in the middle, 'Aiyuan 38' had best freeze resistance. The growth potential and freeze resistance of 'Buzhihuo' in Jinzhou area was the weakest.

\section{Introduction}

Citrus was the most widely cultivated and economically important fruit tree in south China. Hybrid citrus variety was a combination of tangerine, orange and pomelo and a backcross or a return cross between these varieties (Weng and $\mathrm{Xu}, 2006$ ). Aiyuan 38, Chunjian, Buzhihuo, Daya and Wogan were all hybrid citrus varieties introduced from abroad in recent years (Rao, 2015; Huang, etc, 2020; Chen, etc, 2004; Jiang and
Cao, 2011; Chen, etc, 2003), which had performed well in some citrus producing areas and achieved good economic benefits.

In this experiment, the five hybrid citrus varieties which planted in Agricultural Science and Technology Park of Yangtze University were used as materials. Their growth and fruiting habits, botanical characteristics, phenological period and freeze resistance were investigated. We comprehensively analyzed the adaptability of 
different citrus varieties in Jingzhou area from their transplanted performance in order to provide theoretical reference for planting citrus in Jingzhou area Hubei Province.

\section{Materials and Methods}

The experimental materials were 5 hybrid citrus varieties, which were "Aiyuan 38 (red orange rootstock and fragrant orange rootstock)", "Daya", "Chunjian", "Buzhihuo" and "Wogan". The last four varieties were all fragrant orange rootstocks. They were planted in the Agricultural Science and Technology Park of Yangtze University in Jingzhou Hightech Zone Hubei Province in September 2016. The seedlings of the current year were planted. Ten plants were planted for each variety.

Planting water was poured after transplanted, the survival rate was $100 \%$, and routine management was carried out after survival. From February 8 to February 11, 2019, the seedlings were affected by freezing damage in different degrees due to heavy rain and snow, seedlings were affected by freezing damage in different degrees.

The growth characteristics of five citrus varieties were measured on October 20, 2018. Five representative plants from each varieties were selected to measure plant height, crown diameter, dry diameter, leaf length, leaf width, leaf shape index, fall shoot length, summer shoot length, thorn density and wing leaf respectively.

Table.1 Classification standard for freezing injury

\begin{tabular}{|c|l|}
\hline Classification & \multicolumn{1}{c|}{ Cold injury degree } \\
\hline $\mathbf{0}$ & No freezing damage to the whole plant \\
\hline $\mathbf{1}$ & $\begin{array}{l}\text { There are slight spots of frost damage in the main cortex, but the connecting cortex is } \\
\text { mostly intact }\end{array}$ \\
\hline $\mathbf{2}$ & $\begin{array}{l}\text { There are obvious frost spots in the trunk cortex, and a few cortical connections are } \\
\text { intact }\end{array}$ \\
\hline $\mathbf{3}$ & $\begin{array}{l}\text { The cortex around the trunk is necrotic, and the necrotic part is less than } 20 \mathrm{~cm} \text { in } \\
\text { length }\end{array}$ \\
\hline & Trunk around the cortex dead height is greater than $20 \mathrm{~cm}$ \\
\hline
\end{tabular}


Table.2 Growth performance of 5 citrus varieties in the second year after planted

\begin{tabular}{|c|c|c|c|c|c|c|}
\hline Variety & $\begin{array}{l}\text { Aiyuan } 38 \\
\text { (fragrant orange } \\
\text { stock) }\end{array}$ & $\begin{array}{c}\text { Aiyuan } 38 \\
\text { (red orange stock) }\end{array}$ & Buzhihuo & Chunjian & Daya & Wogan \\
\hline Plant height(cm) & $100.0 c \pm 8.51$ & $97.64 c \pm 8.96$ & $81.8 \mathrm{~d} \pm 10.32$ & $117.24 \mathrm{~b} \pm 1.11$ & $128.8 \mathrm{~b} \pm 5.80$ & $155.2 \mathrm{a} \pm 13.60$ \\
\hline $\begin{array}{l}\text { Crown diameter (east and } \\
\text { westx } \\
\text { North and south) }(\mathrm{cm})\end{array}$ & $\begin{array}{l}105.8 \mathrm{~b} \pm 10.4 \times \\
108.20 \mathrm{a} \pm 2.49\end{array}$ & $\begin{array}{l}97.64 \mathrm{~b} \pm 12.1 \times \\
103.40 \mathrm{a} \pm 5.54\end{array}$ & $\begin{array}{l}72.6 c \pm 5.59 x \\
76.80 b \pm 3.27\end{array}$ & $\begin{array}{c}79.6 c \pm 6.18 \times \\
77.40 b \pm 12.34\end{array}$ & $\begin{array}{l}97.4 b \pm 11.8 x \\
85.60 b \pm 9.31\end{array}$ & $\begin{array}{l}122.0 \mathrm{a} \pm 14.45 \times \\
105.34 \mathrm{a} \pm 14.82\end{array}$ \\
\hline Trunk roughness (cm) & $2.37 \mathrm{ab} \pm 0.24$ & $2.29 \mathrm{ab} \pm 0.15$ & $1.93 \mathrm{~b} \pm 0.14$ & $2.69 a \pm 0.37$ & $2.26 \mathrm{ab} \pm 0.23$ & $2.78 \mathrm{a} \pm 0.38$ \\
\hline Leaf length (cm) & $10.0 \mathrm{ab} \pm 0.88$ & $10.78 \mathrm{a} \pm 1.72$ & $8.64 b \pm 0.74$ & $10.26 \mathrm{ab} \pm 1.12$ & $9.48 \mathrm{ab} \pm 1.48$ & $9.66 \mathrm{ab} \pm 1.45$ \\
\hline Leaf width (cm) & $3.74 b \pm 0.42$ & $4.58 \mathrm{a} \pm 0.40$ & $3.70 b \pm 0.68$ & $4.24 \mathrm{ab} \pm 0.28$ & $4.28 \mathrm{ab} \pm 0.68$ & $3.84 \mathrm{ab} \pm 0.74$ \\
\hline Leaf index & $2.69 a \pm 0.24$ & $2.35 \mathrm{ab} \pm 0.30$ & $2.38 \mathrm{ab} \pm 0.33$ & $2.42 \mathrm{ab} \pm 0.17$ & $2.21 b \pm 0.12$ & $2.52 \mathrm{ab} \pm 0.21$ \\
\hline Summer shoot length (cm) & $20.24 b \pm 1.69$ & $20.36 b \pm 4.11$ & $19.40 \mathrm{~b} \pm 3.64$ & $24.72 \mathrm{ab} \pm 2.94$ & $28.66 \mathrm{a} \pm 5.08$ & $31.62 \mathrm{a} \pm 11.36$ \\
\hline $\begin{array}{c}\text { Number of inflorescence per } \\
\text { plant }\end{array}$ & $174.2 \mathrm{a} \pm 23.62$ & $155.8 \mathrm{a} \pm 6.92$ & $20.6 \mathrm{~d} \pm 5.41$ & $33.4 \mathrm{~cd} \pm 19.03$ & $100.8 b \pm 3.19$ & $48.4 c \pm 15.69$ \\
\hline $\begin{array}{l}\text { Number of flowers per } \\
\text { inflorescence }\end{array}$ & $19.4 b \pm 1.14$ & $23.2 \mathrm{a} \pm 2.58$ & $5.20 \mathrm{e} \pm 0.83$ & $7.80 \mathrm{~d} \pm 0.83$ & $10.0 c \pm 1.22$ & $7.20 \mathrm{~d} \pm 1.48$ \\
\hline Number of stamen & $23.8 \mathrm{a} \pm 1.58$ & $23.0 \mathrm{a} \pm 1.92$ & $13.4 c \pm 1.14$ & $14.0 c \pm 1.58$ & $19.4 b \pm 1.51$ & $19.0 b \pm 1.58$ \\
\hline
\end{tabular}

Note: Different lowercase letters following a number in the same line indicate a significant difference of 0.05 , the same as below. Plus or minus for SD. 
Table.3 Comparison of leaf and flower characteristics of Aiyuan 38, Daya, Chunjian, Buzhihuo and Wogan

\begin{tabular}{|c|c|c|c|c|c|c|}
\hline Variety & $\begin{array}{c}\text { Young leaf } \\
\text { colour }\end{array}$ & $\begin{array}{c}\text { Flower } \\
\text { size }\end{array}$ & $\begin{array}{c}\text { Petal } \\
\text { colour }\end{array}$ & $\begin{array}{c}\text { Petal } \\
\text { number }\end{array}$ & Thorn density & Wing leaf \\
\hline $\begin{array}{c}\text { Aiyuan 38 (red } \\
\text { orange stock) }\end{array}$ & $\begin{array}{c}\text { Strong } \\
\text { green }\end{array}$ & small & white & 5 & No thorn & $\begin{array}{c}\text { Del } \\
\text { operator }\end{array}$ \\
\hline $\begin{array}{c}\text { Aiyuan 38 } \\
\text { (fragrant orange } \\
\text { stock) }\end{array}$ & $\begin{array}{c}\text { Strong } \\
\text { green }\end{array}$ & small & white & 5 & $\begin{array}{c}\text { Many thorns and a } \\
\text { bud has a long thorn }\end{array}$ & $\begin{array}{c}\text { Del } \\
\text { operator }\end{array}$ \\
\hline Daya & $\begin{array}{c}\text { Strong } \\
\text { green }\end{array}$ & small & white & 5 & Many and small & Linear \\
\hline Chunjian & $\begin{array}{c}\text { Dark green } \\
\text { Buzhihuo }\end{array}$ & small & white & 5 & few & $\begin{array}{c}\text { Del } \\
\text { operator }\end{array}$ \\
\hline Wtrong & middle & white & 5 & $\begin{array}{c}\text { Many thorns and a } \\
\text { bud has a long thorn }\end{array}$ & Larger \\
\hline
\end{tabular}


Table.4 Antifreeze performance of Aiyuan 38, Daya, Chunjian, Buzhihuo and Wogan

\begin{tabular}{|c|c|c|c|c|c|c|}
\hline Variety & Leaf & Annual branch & Biennial or above branch & Production & $\begin{array}{c}\text { Plant freezing injury } \\
\text { rate }(\%)\end{array}$ & $\begin{array}{c}\text { Frozen } \\
\text { damage } \\
\text { index }\end{array}$ \\
\hline $\begin{array}{l}\text { Aiyuan } 38 \text { (red } \\
\text { orange stock) }\end{array}$ & $\begin{array}{l}\text { Individual blade } \\
\text { crimp }\end{array}$ & $\begin{array}{l}\text { Some late autumn shoots } \\
\text { suffer from cold }\end{array}$ & No damage & $\begin{array}{l}\text { Basically no } \\
\text { impact }\end{array}$ & 20 & 0.07 \\
\hline $\begin{array}{c}\text { Aiyuan } 38 \text { (fragrant } \\
\text { orange stock) }\end{array}$ & $\begin{array}{l}\text { Individual blade } \\
\text { crimp }\end{array}$ & $\begin{array}{l}\text { Some late autumn shoots } \\
\text { suffer from cold }\end{array}$ & No damage & $\begin{array}{l}\text { Basically no } \\
\text { impact }\end{array}$ & 20 & 0.08 \\
\hline Daya & $\begin{array}{l}\text { No more than } \\
1 / 5 \text { victims }\end{array}$ & $\begin{array}{l}\text { Some late autumn shoots } \\
\text { suffer from cold }\end{array}$ & No damage & $\begin{array}{c}\text { Some } \\
\text { influence }\end{array}$ & 40 & 0.42 \\
\hline Chunjian & $\begin{array}{l}\text { Above } 75 \% \\
\text { blade } \\
\text { Yellow and } \\
\text { curly }\end{array}$ & $\begin{array}{c}\text { most of late autumn } \\
\text { shoots were yellow and a } \\
\text { few annual branches were } \\
\text { slightly cracked }\end{array}$ & Almost no damage & $\begin{array}{c}\text { Great } \\
\text { influence }\end{array}$ & 60 & 0.67 \\
\hline Buzhihuo & $\begin{array}{l}\text { More than } 85 \% \\
\text { blade } \\
\text { Yellow and } \\
\text { curly }\end{array}$ & $\begin{array}{l}\text { most of late autumn } \\
\text { shoots were yellow and all } \\
\text { annual branches were } \\
\text { cracked by freezing }\end{array}$ & $\begin{array}{l}\text { Most Biennial or above } \\
\text { branches suffered damage }\end{array}$ & $\begin{array}{l}\text { Great } \\
\text { influence }\end{array}$ & 100 & 0.75 \\
\hline Wogan & $\begin{array}{l}\text { Above } 75 \% \\
\text { blade } \\
\text { Yellow and } \\
\text { curly }\end{array}$ & $\begin{array}{c}\text { most of late autumn } \\
\text { shoots were yellow and a } \\
\text { few annual branches were } \\
\text { slightly cracked }\end{array}$ & $\begin{array}{c}\text { Small biennial branches } \\
\text { suffered damage }\end{array}$ & $\begin{array}{c}\text { Some } \\
\text { influence }\end{array}$ & 40 & 0.44 \\
\hline
\end{tabular}


In terms of the number of stamens, Aiyuan 38 was significantly more than the other four varieties.

Comparison of leaf and flower characteristics among five citrus varieties

It could be seen from table 3, there were quite different in the morphological characteristics among Aiyuan 38, Daya, Chunjian, Buzhihuo and Wogan. In terms of colour of young leaves, all varieties were strong green except that Chunjian was dark green. In terms of flower size, Buzhihuo was middle and other citrus varieties were small. In terms of spike density, Aiyuan 38 (red orange stock) and Chunjian had almost no thorns as the trees age increasing, Daya and Wogan had many and small thorns, Aiyuan 38 (red orange stock) and Buzhihuo had more thorns than other citrus varieties and each bud had one thorn, but the former had a long thorn. In terms of blade shape, Chunjian and Aiyuan 38was similar for inverted triangle shape, Daya and Wogan were similar for linear shape, the blades of Buzhihuo were larger than other citrus varieties.

\section{Comparison of frost resistance among 5 citrus varieties}

As could be seen from table 4, Aiyuan 38 had the best freeze resistance, followed by Daya and Wogan, and Chunjian frostbite was more serious, its freeze resistance was more poor, but Buzhihuo frostbite was most serious, its freeze resistance was most poor.

Therefore, it could be concluded that the freeze resistance of Aiyuan 38 was relatively the best, and that of Buzhihuo was the worst. Therefore, the varieties of Wogan, Chunjian and Buzhihuo should be covered with sunshade net in winter when the weather was very cold, so as to prevent the serious freezing damage. As could be seen from the above, In terms of growth potential, Daya and Wogan performed best, But their freeze resistance were weak, Because they were late-maturing hybrid citrus, need to overwinter to mature, plus the fruit was generally not resistant to freezing, therefore, we could only consider facility cultivation or frost prevention measures. Chunjian and Buzhihuo were the least resistant to freezing, Especially Buzhihuo, not recommended to cultivate in Jingzhou area Hubei Province. Aiyuan 38 had the strongest freeze resistance and was early maturing hybrid citrus, which could be developed in Jingzhou area Hubei Province.

\section{References}

Fa-ling Weng, Jian-guo $\mathrm{Xu}, \mathrm{Pu}-\mathrm{zhi}$ Ke. Hybrid citrus varieties and their cultivation techniques[J]. Zhejiang citrus, 2006, 23 (4) : 10-11.

Bin-ying Rao. Introduction and management of "Aiyuan 38" in central Jiangxi province $[\mathrm{J}]$. Modern gardening, $2015,12: 43-44$

Yong-jing Huang, Wen Wu, Ji-wu Zeng, etc. Introduction of "Red Beauty" hybrid citrus in western Guangdong and key points of cultivation techniques[J]. Fruit trees of South China, 2020, 49 (6) : 144-146

Zhu-sheng Chen, Dong Jiang, Qi-bing Hong, etc. Main characters and cultivation techniques of Chunjian hybrid citrus[J]. Fruit trees of South China,2004, 33 (2) : 5

Dong Jiang, Li Cao. Introduction of late maturity high sugar hybrid citrus variety "Wogan" in Chongqing[J]. Fruit trees of South China, 2011, 40 (5) : 33-34

Zhu-sheng Chen, Dong Jiang, Qi-bing Hong, etc. The introduction experiment of Buzhihuo hybrid citrus[J]. Fruit trees of South China, 2003, 32 (4) : 1-2. 


\section{How to cite this article:}

Tian-zhi Gong, Feng Xu and Guiyuan Wang. 2021. Adaptive Performance of Five Varieties of Hybrid Citrus in Jingzhou Area Hubei Province. Int.J.Curr.Microbiol.App.Sci. 10(10): 156162. doi: https://doi.org/10.20546/ijcmas.2021.1010.018 